\title{
Hermaphroditism in Greek and Roman antiquity
}

\author{
George Androutsos
}

Institute of History of Medicine, University Claude Bernard, Lyon, France

\begin{abstract}
Since antiquity hermaphrodites have fascinated the mind and excited the imagination. In this paper, such subjects are discussed as legends about the nativity of Hermaphroditus, son of Hermes and Aphrodite, the social status of these bisexual beings, and their fate in GreekRoman antiquity.
\end{abstract}

Key words: Female pseudohermaphroditism, Hermaphroditism, Male pseudohermaphroditism.

\section{INTRODUCTION}

"Hermaphroditism" is a state characterized by the presence of both male and female sex organs. Recent developments in the understanding of the pathogenetic mechanisms involved in defective sexual differentiation and the social repercussions of the term hermaphrodite have created the need for new terminology. Hence, such disorders are today designated as genetic defects in the differentiation of the genital system. ${ }^{1}$

\section{THE "FORERUNNERS"}

Beings that are simultaneously both male and female have stirred the human imagination since ancient times. According to Christian theologists and Jewish rabbis, Adam was the first hermaphrodite, a self-sufficient being, like his creator. ${ }^{2}$ After the original sin, Adam was divided into two imperfect sexes, incapable of reproducing on their own.

Address correspondence and requests for reprints to: George Androutsos, 1 Ipirou Str., 10433, Athens, Greece, Fax: +30-2108235710, e-mail: lyon48@otenet.gr Received 05-04-06, Revised 02-06-06, Accepted 15-06-06
The cult of the dual being is also to be found amongst the numerous arcane sciences of the mystical religions of Hindu peoples, before spreading through Syria to Cyprus, and then into Greece. Here it degenerated and met the same fate as the hystero-phallic cults. During such times of decadence, hermaphroditism was looked upon as the embodiment of sexual excess, while for philosophers, it represented the twofold nature of the human being, considered as the original being. ${ }^{3}$

\section{HERMAPHRODITES IN ANCIENT GREECE}

Greek mythology abounds in examples of such dual beings. Even the gods themselves were often hermaphrodites: Dyalos, the androgyne; Arsenothelys, the man-woman; Gynnis, the effeminate; Adgistis, with two sexes; Tireasias who was successively a man and a woman. To justify the existence of hermaphrodites amongst humans, the storyteller Aesop wrote that Prometheus, after producing humans and spending the night drinking, came home inebriated and decided to define the gender of the human beings he had created, hermaphrodites being the result. ${ }^{4}$ Hesiod $^{5}$ states that Aphrodite and 
Hermes united their efforts in order to provide a dowry for Pandora, the first woman.

Hermaphroditus is first mentioned by Theophrastus. ${ }^{6}$ Hermaphroditus was the son of Aphrodite and Hermes. According to the legend, the union of these gods led to the birth of a son of exceptional beauty. At fifteen years of age, he went to Halicarnassus in Caria (Asia Minor). Whilst he was bathing in the waters of a spring, the nymph Salmacis saw him and fell madly in love [The first account of the subject was given by the Latin poet Ennius. ${ }^{7}$ The first Greek to mention it was Strabo, ${ }^{8}$ while Vitruvius $^{9}$ likewise mentioned the subject. However, Ovid, as opposed to Strabo and Vitruvius, lent full credence to the tale]. After trying in vain everything in her power to seduce him, she threw herself into the water, grasping the object of her desire, dragging him down into the depths, and begging the gods to unite them for ever. Her wish was granted, but the being that resulted from their union, Hermaphroditus, was endowed with both sexes: he had a female body and a male sexual organ.

In classical Greek times, Hermaphroditus no longer represented the embodiment of a religious symbol but rather the hero of a Homeric legend. The story begins when Hephaestus comes upon his wife Aphrodite deceiving him with Ares, the god of war. Using an invisible net, he imprisons the couple in the bed and calls upon all the gods of Olympus to bear witness to this intolerable offence. However, to his consternation, he realizes that he has caused only general hilarity amongst the gods. Apollo then asks the god Hermes whether he would feel aversion at being in Ares' shoes. When Hermes avows that he would not be saddened. Aphrodite, flattered by Hermes' words, offers herself up to her admirer for a night of love. The fruit of the divine union between Hermes and Aphrodite was Hermaphroditus.

The idea of transformation goes very far back in Greek literature. It was already present in the Iliad and in the Odyssey, and was perpetuated in the poetry of the $5^{\text {th }}$ and $4^{\text {th }}$ centuries BC. ${ }^{10}$

In Plato's Banquet, ${ }^{11}$ Aristophanes, discoursing on the gender issue, states that the human race was originally of three genders: male, female and an- drogyn. The androgyns had both male and female sexual organs. They also had two bodies, one male and one female, and two converse faces on the same head. The androgyns were aware of their physical perfection, the total independence that they enjoyed-since they were able to reproduce aloneand their invulnerability. This feeling of omnipotence was not to the taste of Zeus who decided to "separate them into two equal parts": one male and one female. The sex thereby became the gender resulting from this separation". Since then the human body has been pierced in places as the cleft made by Zeus was repaired by Hermes and each half of the primitive androgyn is looking for his or her other half.

\section{HERMAPHRODITES IN ROMAN TIMES}

Ovid was the first to relate the story of Hermaphroditus and the only one to establish an explicit link between bisexuality and passive male homosexuality. In his Metamorphoses, ${ }^{12}$ he mentions six sex changes: men, Tiresias and Sithon, being turned into women; Iphis, a woman, who became a man; Maestra, another woman, who became a man, as did Kainis becoming Kaineus. Hermaphroditus, or rather the being created by the fusing of Salmacis and Hermaphroditus, was the only one bestowed with the two sexes simultaneously. Ovid also described the increasingly male appearance of a young Greek girl aged 13: "You are a young man, although just recently you were a woman, were you not?" According to the arguments, the masculinized Greek girl was the victim of an excessive production of male hormones.

Titus-Livy ${ }^{13}$ relates that when Italy recovered from occupation by Carthage, monsters appeared, including two androgynous children: “...all these events appeared to be due to a freak of nature which mixed genders. In particular, we were horrified by the hermaphrodites". A list of sixteen accounts concerning hermaphrodites during the period between 209 and 92 B.C. was written by Titus-Livy.

Pliny the Elder ${ }^{14}$ also mentions some cases of sex changes: "The accounts of women changing into men are not just fables. ...In Casinum a girl turned into a boy. Licinus Mucianus said that he personally knew 
a man called Arecson in Argos, who changed his name to Arescusa and even found herself a husband; later on, he grew a beard with all the signs of virility, and took a wife. This author was witness to a similar adventure with a boy from Smyrna. I have seen with my own eyes, in Africa, a citizen of Thysdrus change into a man on his wedding day". Pliny also asserted that hermaphrodites were a distinct race living in a remote part of Africa.

Soranos of Ephesus, ${ }^{15}$ in his main work Women's diseases, documented several cases of gender ambiguity and observed that women with a masculine appearance do not have periods; he describes the possibility of a hypertrophic clitoris in such cases.

The legend concerning the Roman Emperor Elagabalus (218-222 AD), who is said to have offered half the Roman Empire to the physician who could equip him with female genitalia, represents a famous instance of "sex change". ${ }^{16}$

\section{SOCIAL STATUS AND THE FATE OF HERMAPHRODITES IN ANCIENT GREECE AND ROME}

Most ancient people eliminated children with doubtful gender: for Greeks this was an expression of their need to demonstrate the physical beauty of their race, while among the Romans it was an interpretation of this aberration as being a bad omen. ${ }^{17}$

Although the fate of bisexual beings became less cruel as time went by, the only possible status for such persons was on the borderline of society. In periods of crisis, hermaphrodites became scapegoats for fear and uncertainty. When a child was born with abnormal sexual organs, he was immediately sentenced to death by the community, who interpreted this as a sign of divine wrath. ${ }^{18}$ During Greek and Roman antiquity a whole series of laws ordered parents to expose their new-born children. Abnormal children were seen as signs of evil that had to be removed by the state by being cast out beyond the limits of the city. However, although this was regarded as a necessary 'purification' of the city, it was important to avoid directly killing these abnormal children and burying them. ${ }^{19}$ In killing them, there was a risk of turning them into "biaiothana- toi" (= victims of a violent death); it was believed at the time that they would come back to take their revenge or "aoroi" (= struck by premature death) ${ }^{20}$ So they preferred to expose them, offering them up to the will of the gods who could do with them as they wished. This custom only died out during the first centuries $\mathrm{AD}$.

As far as eliminating the hermaphrodite was concerned, the list of the sixteen cases of hermaphroditism mentioned above is an extremely interesting document. On ten occasions the hermaphrodite is abandoned in the water (e.g. the sea); in another case the hermaphrodite was sentenced to death. The Romans' pitiless attitude to sexual ambiguity, seeing it as a threatening omen, was not limited merely to new-born babies. Diodorus of Sicily ${ }^{21}$ reports a woman who turned into a man. The senate once informed, the woman was burned at the stake.

Hermaphrodites in Rome, at certain periods of time, were used as objects of pleasure. Generally speaking, these human beings with two sexes were not able to find their place in any of the early societies, since they represented a threatening gap with regard to the norm, implying a clear biological differentiation between men and women, and thus a differentiation in roles. Any form of uncertainty concerning a clear distinction between the sexes was perceived as a threat. And it took a very long time for the fear brought about by this uncertainty to diminish to the extent that it was no longer necessary for these beings with two sexual organs, one male and one female, to be callously and mindlessly destroyed.

\section{TRANSFORMATIONS OF THOUGHTS IN THE GREEK-ROMAN WORLD ABOUT HERMAPHRODITES}

With the passage of time, the antique world as a whole started to see hermaphrodites as simply amusing quirks of nature. A good example of this reaction is to be found in the writings of Diodorus of Sicily. Using the cases of Heraos and Kallo,${ }^{22}$ he showed that hermaphroditism was a natural phenomenon which can be surgically corrected, and that such beings, having changed gender after an operation, can play a role in society, although this is not 
an easy feat to accomplish. Another example of a change in attitude is the story of Polycritus, as related by Phlegon de Tralles" 23 : Polycritus, an Aetolian, married a Locrian woman; he shared her bed three nights running, and on the fourth, he died. His wife gave birth to a child with two sexes. The upper parts of the genitals were firm and male, whilst those between the thighs were soft and female. The family, astonished, took the child to the public square and convened an assembly to deliberate on the fate of the child. Since he had two sexes, the child was a 'monster', according to the definition of Aristotle, ${ }^{24}$ employing the term in a biological content "Anyone living who is not akin to his parents is to some extent already a monster, because in this case, nature has moved away from the genetic types". Suddenly Polycritus reappeared and begged them to give him back his child. He added that he forgave them for behaving in this way, as he understood their difficulty in understanding something so extraordinary. But, seeing that they were not paying any attention to what he was saying, he tore it apart and gobbled it up, except for the head, and suddenly disappeared. Then the child's head started to talk and announced oracularly what was going to happen..."

Fortunately, nowadays individuals with such problems are not considered "monsters" but patients with defects in the differentiation of the genital system and most of them are successfully managed.

\section{REFERENCES}

1. Hughes IA, Houk C, Ahmed SF, Lee PA, LWPES Consensus Group; ESPE Consensus Group, 2006 Consensus statement on management of intersex disorders. Arch Dis Child 91: 554-563.

2. Genese chap. I, verset 27

3. Platon 1990 Les Lois. Traduction par Anissa CastelBouchouchi, Gallimard, Paris, IX, 868 d-e.

4. Monestier M 1981 Les monstres. Editions du Pont Neuf, Paris, pp, 205-212.
5. Hesiode 1998 Les travaux et les jours. Traduit par P. Terreaux. Arléa, Paris; pp, 116-122 \& 76-77.

6. Theophraste 1965 Caractères. Les Belles Lettres, Paris; pp, 27-38.

7. Ciceron 1965 Des dévoirs. Collection des Universités de France, Paris, I, 61.

8. Strabon 1986 La Géographie, Les Belles Lettres, Paris, XIV 2:16:50.

9. Vitruvius 1931 On architecture. F Granger. Loeb Classical Library, 2 vols, II 8, 11-12: 50-51.

10. Speert H 1973 Histoire illustrée de la gynécologie et de l'obstétrique. Dacosta, Paris, pp, 32-35.

11. Platon 1992 Le Banquet. Trad par Emile Chambry. GFFlammarion, Paris, 189d-190c: 70, 19la-b:74, 191d-e: 73, 192c-e: 74-75, 193a-b:76.

12. Ovide 1966 Les métamorphoses. GF-Flammarion, Paris, pp, III 316-339, IV 285-388, XI 50-55 22.

13. Tite-Live 1998 Histoire romaine. L. XXXVI à XL. Flammarion, Paris XXVII 37, 5 sq: 30-31.

14. Pline l'Ancien 1997 Histoire Naturelle. Les Belles Lettres, Paris; Livre VII, chap. IV.

15. Soranos d'Ephese 1990 Maladies des femmes. Trad. Gourevitch. Belles Lettres, Paris; pp, 72-75.

16. Green R 1966 Transexualism: Mythological, Historical, and Cross-Cultural Aspects. Appendix C In: The Transexual Phenomenon by Harry Benjamin, New York Spring.

17. Gould G, Pyle W 1984 Les curiosités médicales. SipMonaco, Paris, pp, 249-250.

18. Martin E 1880 Histoire des monstres depuis l'antiquité jusqu'à nos jours. Reinwald, Paris; pp, 2-9.

19. Cumont F 1945 Virgile et les morts prématurées. Conférences de l'ENS, Publications de l'École Normale Supérieure, Section des Lettres II, Paris, Droz; pp, 132152.

20. Brisson L. Le sexe incertain: androgynie et hermaphrodisme dans l'Antiquité gréco-romaine. Les Belles Lettres, Paris; 13-18.

21. Diodore de Sicile 1995, Bibliothèque (Photius). Univers. de France, Paris, codex 244,378b-379a.

22. Androutsos G, et al, 2001: Les premières opérations de changement de sexe dans l'antiquité. Andrologie 2: 89-93.

23. Phlegon de Tralles 1966, De mirabilibus. A. Giannini, Milan 2: 14-17, 3, 359-364: 21-22.

24. Aristote 1961, De la Génération des animaux. Trad. P. Louis. Les Belles Lettres, Paris, IV, 2, $767 \mathrm{~b}$. 